\title{
Preparing the Next Generation of Science Teacher Educators: A Model for Developing PCK for Teaching Science Teachers
}

\author{
Sandra K. Abell · Meredith A. Park Rogers • \\ Deborah L. Hanuscin • Michele H. Lee · \\ Mark J. Gagnon
}

Published online: 5 November 2008

(C) Springer Science+Business Media, B.V. 2008

\begin{abstract}
Science education doctoral programs often fail to address a critical piece-the explicit attention to the preparation of future science teacher educators. In this article, we argue that, in addition to developing skills and a knowledge base for research, doctoral students must be given the opportunity to observe, practice, and reflect on the pedagogical knowledge necessary to instruct science teachers. In particular, we contend that the construct of pedagogical content knowledge (PCK) can be adapted to the context of knowledge for teaching science teachers. We use the PCK construct to propose a model for the development of knowledge for teaching science teachers, grounded in our experiences as doctoral students and faculty mentors. We end by recommending a vision for doctoral preparation and a new standard to be included in the ASTE Professional Knowledge Standards for Science Teacher Educators.
\end{abstract}

Keywords Science teacher education - Doctoral programs $\cdot$ PCK

S. K. Abell $(\bowtie)$ · D. L. Hanuscin · M. H. Lee · M. J. Gagnon

Science Education Center, University of Missouri, Columbia, MO 65211, USA

e-mail: abells@missouri.edu

D. L. Hanuscin

e-mail: Hanuscind@missouri.edu

M. H. Lee

e-mail:mhl3h6@mizzou.edu

M. J. Gagnon

e-mail: mjgkt3@mizzou.edu

M. A. P. Rogers

Indiana University, Bloomington, IN 47405, USA

e-mail: Mparkrog@indiana.edu 
In recent surveys of doctoral students in all fields (including arts and sciences, engineering, social sciences, and humanities), respondents shared concerns that an overemphasis on research in their programs led to inadequate preparation for teaching, curricular planning, collegiality, and service (Fagen and Niebur 2000; Nyquist and Woodford 2000). In one study (Brown et al. 2001), roughly half of respondents felt they received inadequate preparation as teaching assistants and lacked mentoring to improve their teaching skills. Much like doctoral programs in other fields, science education doctoral programs help students build a knowledge base and learn to do research in their discipline. However, research demonstrates that this knowledge base often lacks an explicit emphasis on learning about science teacher education. One indication of the lack of explicit attention to developing science teacher knowledge for teaching teachers is the coursework required of doctoral students. In a national survey of doctoral programs, Jablon (2002) found that most programs required coursework in research methods, nature of science, and science education curriculum, among others. Yet, within a list of 13 science education topics typically found in doctoral courses, the topic of science teacher education did not appear. Furthermore, according to Jablon:

Even though $100 \%$ of the doctoral program heads expected their graduates to be able to teach methods courses and supervise student teaching (96\% expected proficiency at inservice workshops), only $34 \%$ required their graduates to be involved in a mentored teaching of a methods course, student teaching, or inservice workshops. Forty two percent said the students could do this as an elective and $24 \%$ said their graduates had no opportunity to be mentored in any of these skills (p. 17).

Clearly our science education doctoral programs are missing a critical piece (Abell 1997) - the explicit attention to the preparation of future science teacher educators. We argue that, in addition to developing skills and a knowledge base for research, doctoral students must be given the opportunity to observe, practice, and reflect on the pedagogical knowledge necessary to instruct science teachers.

In 1997 the then Association for the Education of Teachers in Science published a set of standards for "those individuals designing and implementing teacher education programs, institutes, workshops, etc." (Lederman et al. 1997, p. 233). These Professional Knowledge Standards for Science Teacher Educators include expectations that teacher educators will have a strong science knowledge base; understand science pedagogy, curriculum, instruction and assessment; and know about learning and cognition. Each of these standards focuses on science education as applied to K-12 education. A fifth standard discusses preparation for research, and a sixth standard applies to knowledge and experience in offering professional development "workshops and institutes" (p. 239). However, the standards do not address a critical aspect of what science teacher educators should know: how to teach future science teachers. If we assume that the Standards define the disciplinary knowledge base and guide the design of doctoral programs, then we must include explicit attention to developing knowledge for teaching science teachers as an important goal. 
The purpose of this paper is to use our diverse experiences as faculty members and graduate students to propose a model for the development of knowledge for teaching science teachers. This model can be used by science educators to consider the design of their doctoral programs as well as to generate research programs around the learning of doctoral students. First we present a conceptual framework that can help situate our work in preparing future science teacher educators. Next we provide vignettes of our experiences as mentors and mentees in learning to become science teacher educators that illustrate the conceptual framework in action and provide a basis for our model. Although our vignettes are grounded in our experiences as elementary science teacher educators, our model describes a trajectory for the development of knowledge for teaching science teachers that we believe applies more broadly to the preparation of science teacher educators at all levels, although this hypothesis remains to be tested. We end by recommending a vision for doctoral preparation and a new standard to be included in the ASTE Professional Knowledge Standards for Science Teacher Educators.

\section{Conceptual Framework}

Shulman (1986) posited a specialized knowledge that distinguishes teachers from subject matter specialists-pedagogical content knowledge (PCK). According to the PCK framework, knowing science is a necessary but not sufficient condition for teaching. Science teachers must also have knowledge about science learners, curriculum, instructional strategies, and assessment through which they transform their science knowledge into effective teaching and learning. These types of knowledge, or PCK, are filtered through a teacher's orientation to science teaching as they are put into action (Abell 2007; Grossman 1990; Magnusson et al. 1999). Although we agree with Gess-Newsome (1999) that PCK is more powerful than its constituent parts and that experienced teachers draw upon multiple knowledge types simultaneously as they make instructional decisions, we believe that science teacher educators can give explicit attention to the individual PCK components as a way to scaffold learning for novice teachers.

We contend that a parallel form of PCK exists for science teacher educators. In this case, the subject matter knowledge that a science teacher educator needs includes both science content and knowledge for teaching science. A science teacher educator's PCK includes his/her knowledge about curriculum, instruction, and assessment for teaching science methods courses and supervising field experiences, as well as his/her knowledge about preservice teachers and orientations to teaching science teachers (see Fig. 1). For example, the science teacher educator should understand the points of resistance that prospective teachers might experience when learning about science teaching. Furthermore, the science teacher educator should know strategies for helping future teachers confront their naïve conceptions of science teaching and learning (Abell et al. 1998) and find suitable alternative views. Science teacher educator PCK is filtered through their orientations to teaching science teachers (Abell and Bryan 1997; Russell and Martin 2007) as they design and carry out instruction. The model we describe for learning to teach 


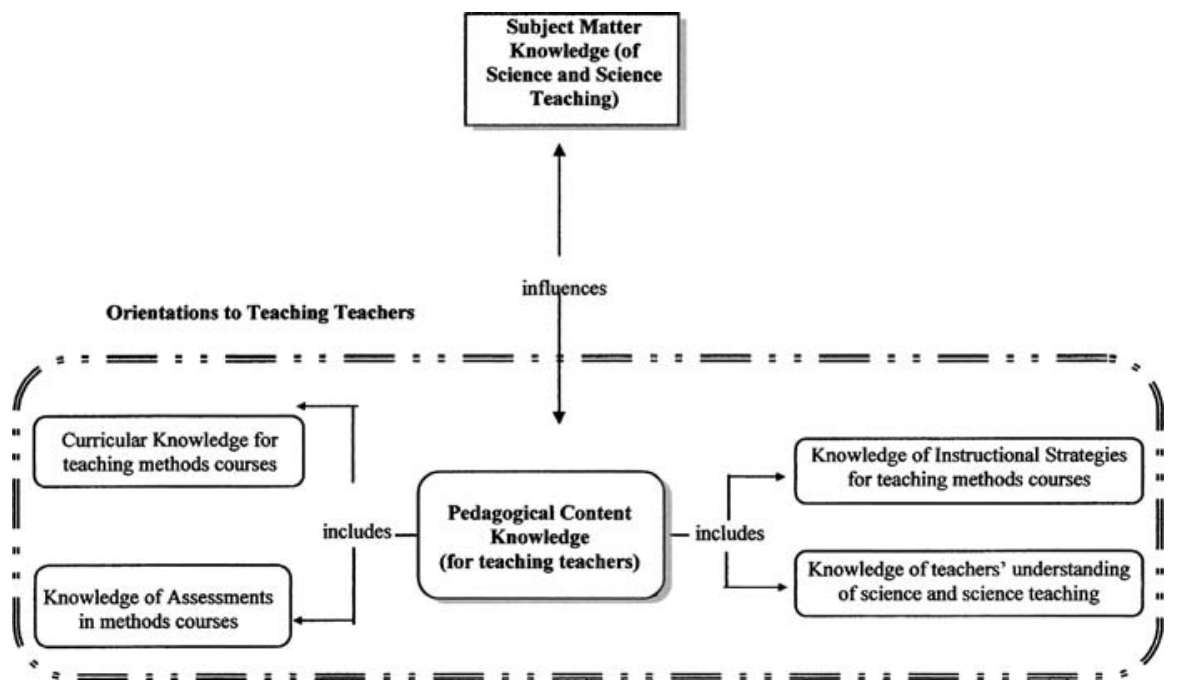

Fig. 1 A model of PCK for teaching science teachers (adapted from Grossman 1990 and Magnusson et al. 1999)

science teachers is based on our view that to support novice science teacher educators' learning about teaching teachers, we should attend explicitly to the individual components of PCK as well as provide opportunities for doctoral students to draw upon multiple components as they make instructional decisions.

In recent years, there has been increasing recognition that learning to teach in grades $\mathrm{K}-12$ is a lifelong enterprise that comprises a professional continuum (Feiman-Nemser 2001). This continuum originates in K-12 formal education with an apprenticeship of observation (Lortie 1975), and proceeds through teacher preparation, induction, and recurrent professional development. Teachers' learning needs change along this continuum as their PCK develops. We hypothesize that a similar professional continuum exists for science teacher educators, but has yet to be researched. Future teacher educators begin their professional development as classroom teachers, progress through their doctoral preparation, and proceed into the beginning years in the professoriate. Their development in the doctoral program is influenced by their incoming subject matter knowledge (of science and science teaching), their incoming PCK for teaching teachers, and by their opportunities and experiences in the doctoral program.

Learning theorists propose that learning is situated in authentic contexts which allow learners to participate in communities of practice (Brown et al. 1989; Lave 1988; Lave and Wenger 1991; Rogoff 1990). It is our claim that doctoral programs should function as a community of practice through which its members (faculty members and students) develop a disciplinary knowledge base, skills for designing and carrying out science education research, and knowledge for teaching science teachers. We believe that explicit attention to developing components of PCK for teaching future science teachers is a critical aspect of this community of practice. 
However, we acknowledge that the typical experiences of science education doctoral students (e.g., Jablon 2002) may not explicitly address learning about teaching science teachers.

\section{Developing PCK for Teaching Science Teachers}

Our own experiences as doctoral students and faculty members across three different universities illustrate that the preparation of doctoral students to teach science teachers varies greatly in terms of opportunities to learn about science teacher education and explicit attention to developing PCK. For example, doctoral students may have no opportunity to teach or even co-teach a methods course during their graduate education, and will not do so until they obtain an academic position. Other graduate students may find themselves in teaching positions in which they are the instructor of record with the full responsibilities of a faculty member, but provided little or no mentoring. Still others experience a highly structured experience in which they are expected to implement a syllabus and pre-planned activities identical to those of a faculty member, rather than learning to make their own instructional decisions as teacher educators. We argue that none of these opportunities provides the optimum environment for supporting the development of PCK for teaching science teachers, because they ignore the learning needs of teacher educators at various phases of the professional continuum.

We offer a set of vignettes based on our experiences that illustrate meaningful opportunities for developing PCK for teaching science teachers. Each vignette demonstrates the development of a specific PCK component. Together, the vignettes illustrate the nature and diversity of experiences through which PCK for teaching science teachers can be made explicit in doctoral programs. We present the vignettes in a sequence representing various learner roles and career phases along the professional continuum. These vignettes highlight various forms of legitimate peripheral participation (Lave and Wenger 1991) through which doctoral students might develop PCK for teaching science teachers.

\section{Vignette 1: Developing PCK of Instructional Strategies for Teaching Teachers (Gagnon)}

My development of PCK of instructional strategies for teaching science teachers was enhanced by a combination of experiences at the beginning of my doctoral program. First, I enrolled in a doctoral seminar course, "Research, Policy, and Practice in Science Teacher Education," taught by my advisor. In that course, we read about and discussed, among other things, the research concerning best practices in instructional strategies for preservice science teachers. Concurrently with this formal course, I was assigned to observe an elementary methods course taught by a different science educator.

During the semester, I had opportunities to think about instructional strategies through observing them in action in the methods course, while reading and discussing research about them in the doctoral seminar. One of the goals we 
established for the observation was for me to focus on the instructional strategies the instructor used during small and whole group discussions. I observed the instructor guide elementary methods students through a series of discussions over a period of several weeks. She modeled various discussion strategies (for example, asking students to discuss in their small groups before talking in the large group; asking students to refer to their science notebooks during discussions) and asked the prospective teachers how they could use such strategies in their own classrooms. As the course progressed, the preservice teachers became more adept at employing various roles and responsibilities in small and large group discussions.

Meanwhile in the doctoral seminar, I was reading and discussing research on teacher education. Our main text was the Cochran-Smith and Zeichner (2005) book, Studying teacher education: The report of the AERA panel on research and teacher education, but we also read and discussed research on instructional strategies specific to science teacher education. I was able to reflect on the research and apply it to my developing knowledge of instructional strategies for teaching teachers. This reflection during both the doctoral seminar and the methods course was invaluable to me later in the semester as I began to co-facilitate a discussion group for the field experience associated with the methods course. With my faculty mentor, I developed learning goals and guiding questions to facilitate each seminar discussion. I employed the strategies I had learned and asked the prospective teachers about their success with discussion strategies in their classrooms.

As I look back on these experiences, I realize that the knowledge I gained in the doctoral seminar gave me a unique perspective from which to observe instructional strategies in the science methods course. Subsequently, as I reflected on my experience in observing the science methods class, I applied similar instructional strategies to the field experience discussion group. My role changed from outside observer to inside beginning apprentice as the semester progressed. I developed a deeper PCK of instructional strategies for teaching preservice teachers through the synergy of these experiences. The opportunity to read research about best practices gave me the ability to observe in a more focused way. The opportunity to observe helped me apply strategies in my teaching. And the opportunity to try out those strategies brought life to new things I read.

Vignette 2: Developing PCK of Curriculum for Teaching Teachers (Park Rogers)

My formal experience in preparing to become an elementary science teacher educator began during the second year of my doctoral program and involved a semester-long independent readings course with my faculty advisor. I viewed this as a master/apprentice relationship where $\mathrm{I}$, as a newcomer to the community of practice of science teacher education, would learn from a master who had taught elementary science methods courses for 15 years and published numerous papers on the topic. One purpose of this apprenticeship was to prepare me for teaching an early childhood science methods course independently in the future. To provide some structure to the independent study, we drew up a contract outlining the goals, my responsibilities, and what would represent a summative assessment of my PCK 
for teaching preservice teachers at the end of the semester. The independent study involved one-on-one informal meetings every 2-3 weeks to discuss readings that pertained to the development of my PCK for teaching early childhood science methods. As a learner in this apprenticeship, my responsibilities were to read the chapters/articles recommended by my advisor and come to meetings prepared to discuss themes that emerged from the readings. My summative assessment would be to develop a syllabus for my future teaching of early childhood science methods. The syllabus, where I would delineate the goals and topics for the course, would reflect my PCK for early childhood science methods curriculum in particular.

After we had designed the independent study and selected the readings, we dug in. We discussed readings around themes that would help me structure the curriculum of the methods course, such as: using an inquiry-based approach to teaching science (e.g., using the $5 \mathrm{E}$ model to plan instruction), identifying and implementing purposeful questioning techniques, and developing a community of science learners. As a newcomer, I needed help in sorting out the most important ideas from the readings and thinking about how those would apply in the setting of the early childhood science methods course. My advisor acted as a guide, asking questions to focus my reading and thinking, and suggesting supplementary readings to deepen my understanding. For example, Sheila Jelly, in Wynne Harlen's book Primary Science: Taking the Plunge (2001), describes the difference between productive and unproductive questions in teaching science and Jos Elstgeest distinguishes among five types of productive questions-attention-focusing, measuring, comparison, action, and problem-posing. While the descriptions these authors provided were clear to me for teaching elementary science, I wondered about the topic of questioning with preservice teachers-what should my goals be, where in the curriculum might this topic be most effective, what topics should come before, and what would logically follow? My advisor directed me to read Duckworth's (1987) chapter on "Teaching as Research" to understand how to engage teachers with investigative questions and the Harlen et al. book (2003) that uses productive question categories in actual science learning scenarios.

Another way my advisor guided me in the independent study was through the assignment to design a course syllabus for early childhood science methods. At one of our meetings, she sat down with the pile of materials we had been reading, our notes, and a semester-long calendar. "OK," she said, "let me show you how I might plan a methods course." She walked through the processes she used to synthesize her knowledge of curriculum for teaching teachers while she structured a 16-week methods course. As she planned aloud, I observed, took notes, and began thinking about my future teaching of the early childhood methods course. With this guidance, I was ready to put my curricular ideas into place through designing my own course syllabus. This process included several iterations of writing, getting feedback from my advisor, and revising before we were both happy with the final product.

One outcome of this apprenticeship experience was my realization that the curricular goal of any methods course should be to develop simultaneously four aspects of PCK for teaching science-knowledge of learners, curriculum, instruction, and assessment. I thought about how the topic of productive questions could be a springboard for thinking about each of these aspects. I also decided where in the 
course sequence this topic would work best. By the end of the independent study, my knowledge of what to address in the curriculum for an early childhood science methods course included: understanding young children and their science abilities; setting goals for science learning; designing inquiry-based instructional strategies, and developing assessment strategies that seamlessly integrate the science curriculum.

\section{Vignette 3: Developing PCK of Assessment for Teaching Teachers (Lee)}

In my second year of the $\mathrm{PhD}$ program, I had the opportunity to apprentice with a professor who taught an elementary science methods course. During the apprenticeship, I focused on methods course assessment. I observed her methods course in action, took field notes, reflected on assessment techniques through conversations with the professor, practiced responding to and evaluating student work, and reflected on my own methods course assessment knowledge through personal journal writing. The following semester, I was given an assistantship and assumed responsibility for teaching my own section of the methods course in partnership with the professor.

Working together, we selected initial pre-assessments to administer to our students including: the Draw-A-Scientist Test (Chambers 1983); card sort of elementary science teaching and learning (based on Friedrichsen and Dana 2003); and science autobiography (Koch 1990). We reviewed and discussed our students' responses during weekly meetings and in informal conversations, through which I gained insight into prospective teachers' ideas about science and science teaching. For each methods course teaching episode we planned, we targeted prospective teachers' prior knowledge, discussed how to align assignments to the course goals, developed scoring rubrics to evaluate students' work products, and strategized how we would use what we learned from the assessment to plan instruction. In this manner, I began to view teaching and assessment as a cyclical process.

Consistent with this cycle of assessment, we asked students to construct a portfolio at the end of the semester as an authentic summative assessment of their growth. We asked them to revisit their initial ideas about science and science teaching, and to reflect on their progress toward each of the course goals throughout the semester. During my previous apprenticeship, I had reviewed students' portfolios and sat in on several of the portfolio conferences the professor held with her students. Now, as a partner, I was able to provide feedback and input as to how portfolio conferences should be structured, what questions would be important to ask, and how we would use students' oral responses as part of the evaluation.

Through the partnership experience with this faculty member, I gained a greater appreciation of what and how I needed to assess within the methods course setting, thus developing my PCK of assessment for teaching teachers. I recognized that it was important to assess each preservice teacher's PCK for teaching elementary science (knowledge of learners, curriculum, instruction, and assessment), their subject matter knowledge (understanding of the nature of science, inquiry skills, conceptual understandings) and their general pedagogical knowledge (e.g., of learning and classroom management). I also learned various strategies to assess 
students both formally and informally, and to guide them in self-assessment. Through this partnership, I became more facile at developing and using rubric criteria to evaluate levels of sophistication and diagnose student difficulties, as well as using assessment to inform my instruction.

\section{Vignette 4: Developing PCK of Learners for Teaching Teachers (Hanuscin)}

Toward the end of my doctoral program, I was independently responsible for developing and teaching my own section of an elementary science methods course. Concurrently, I was enrolled in a 1-h seminar Teaching in Teacher Education that was intended for graduate students throughout the college who were engaged in teaching prospective teachers. As colleagues, we met on a weekly basis to discuss and compare our students' ideas and their work-what surprised us, what matched our expectations, and how we might address their naïve conceptions and beliefs about teaching. Our collegial conversations were a great source of support and afforded us the opportunity to make reflection a regular and deliberate part of our practice, which helped to deepen my PCK for teaching teachers. These discussions allowed me to make explicit many of the tacit ideas about preservice teachers as learners that guided my teaching, including my knowledge of the naïve ideas and points of resistance that future teachers encounter when learning to teach science, such as their negative feelings about science and stereotypical views of scientists. Through this process, I was able to align my PCK of learners with my teacher education practice, and to organize my course more effectively to support students in grappling with their feelings and ideas about science.

My knowledge of learners was the result of carefully planned assessments and class activities designed to elicit students' ideas about science and science teaching. Examples included the writing of a science autobiography (Koch 1990), various card-sort activities (e.g., Friedrichsen and Dana 2003), and a final portfolio assignment in which students reflected on their learning throughout the course. To develop my knowledge of learners as I taught the course, I focused on the ideas that students expressed in these assignments, as well as during class discussions and small-group activities. Throughout the semester, I looked for patterns in students' work and used these as a basis to plan my next steps in instruction.

One theme that emerged from students' discussions and course assignments was their belief that science is an objective endeavor, carried out by strictly adhering to the scientific method. To address this naïve idea, I planned explicit-and-reflective activities (e.g., Akerson et al. 2000) to address preservice teachers' ideas about the nature of science. Similarly, I encountered a point of resistance to teaching science as inquiry when one of my students expressed the belief that inquiry was only appropriate for high-ability learners - this was a barrier to learning to teach science as inquiry that I had read about in my prior coursework. I realized that many of my students had not experienced inquiry as learners, nor had they observed teachers using inquiry in their field experiences. I was able to draw on my previous elementary teaching experience, as well as videocases of elementary science teaching (e.g., Abell 2003; Abell and Cennamo 2004) to illustrate inquiry as an 
achievable goal in the elementary classroom. I also planned inquiry experiences in which my students could participate as learners.

My experience as an independent instructor was dialectical. I employed the PCK for teaching teachers that I had developed in doctoral courses while I taught the methods course. Yet I also developed new PCK of learners as I worked with the future teachers in my course. Teaching an elementary science methods course independently was a challenge that I was well-prepared to take on at that point in my doctoral program.

\section{Vignette 5: Developing Orientations for Teaching Teachers (Abell)}

I had been teaching elementary science methods for a few years when I landed my first NSF grant as PI. The goal of the grant was to develop videocases of elementary teachers using best practices in their teaching. We would then use the videocases in our teaching of the elementary science methods course. The development of the videocases went according to schedule (see Abell and Cennamo 2004). But when the videocases were finished, we faced the challenge of inventing pedagogies for using the videocases in the methods course. I enlisted the assistance of Lynn Bryan, a doctoral student at the time.

Lynn delved into the research literature on case-based pedagogy and reflection in teacher education. We met regularly to discuss the literature. We designed and piloted reflection tasks to accompany the videocases. At this point we faced a major challenge. To use the videocases as we intended would consume a great deal of class time. Something else in the course would have to go to make way for the videocases. That is when Lynn and I started to consider our orientations to teaching science teachers. We had to make our goals and purposes for the course explicit to ourselves in order to judge what to keep and what to omit. Through our collaborative thinking, we came to understand that several orientations to science teachers were possible, but that our own orientation involved an emphasis on teacher reflection in learning from experience (Abell and Bryan 1997).

I learned three important lessons from this experience. First, I realized that my knowledge for teaching teachers continued to develop beyond the doctoral program as I continued to teach and reflect upon my teaching. Second, I realized that my knowledge for teaching teachers was enhanced through mentoring doctoral students. In other words, both Lynn and I learned from our collaboration. Third, I learned that, in addition to observing and teaching methods courses, doctoral students could develop their PCK for teaching teachers in a research and development setting. Lynn was not teaching the methods course at the time of her involvement in the NSF grant. Yet our collaboration in designing new pedagogies for the elementary methods course generated new knowledge for teaching teachers for both of us, including new ideas about orientations that we could share with the larger science education community. The reflective orientation (Abell and Bryan 1997) that guided our reformulation of the methods course included reflection via videocases, and directly impacted my teaching of future teachers. 


\section{A Model of PCK Development for Science Teacher Educators}

Based on our learning experiences in becoming science teacher educators as captured in the vignettes, we posit that a continuum of professional learning exists, much like that for K-12 teacher learning. Furthermore, we believe that learning to teach science teachers will be most fruitful when explicit attention is paid to developing PCK for teaching teachers through various learner roles. Thus we propose a model and present one possible trajectory of development for prospective science teacher educators (Fig. 2). This model is derived from and represents our collective experience in becoming science teacher educators at three different universities.

We offer the model in part as a guide for planning a cohesive program for the preparation and continuing education of science teacher educators. Across the phases of career development - from the apprenticeship of observation within one's own teacher preparation program and classroom teaching experiences, through the doctoral program, and into the beginning years in the professoriate-we suggest a scaffolded sequence of learner roles. These roles define various opportunities for legitimate peripheral participation (Lave and Wenger 1991) in the doctoral program. As an individual moves through the career phases and participates in various learner roles, he/she defines a trajectory in developing PCK for teaching teachers. Below we discuss five possible learner roles and connect them to our PCK vignettes. We recognize that these roles are not discrete stages, but can constitute a continuum of learning. We have also located the vignettes on the model (see Fig. 2) in order to illustrate a possible learning trajectory.

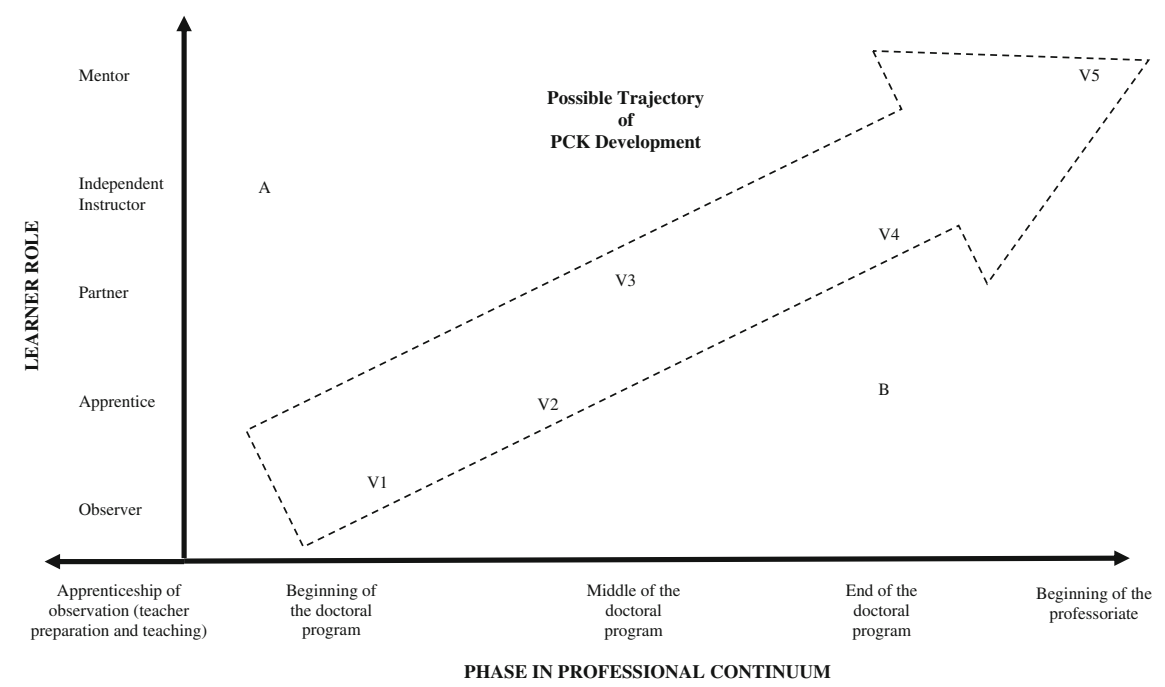

Fig. 2 A model of the development of PCK for teaching science teachers 


\section{Observer}

Just as undergraduate students lack the experience of how a classroom functions from a teacher's perspective, a beginning $\mathrm{PhD}$ student lacks the experience of how a college/university classroom functions from an instructor's perspective. Doctoral students have spent many years in the apprenticeship of observation (Lortie 1975) to be teacher educators, both during the formal teacher preparation program and as teachers themselves. However, they have viewed these experiences through the lens of a future or practicing teacher, not as a teacher educator. We acknowledge that not everyone begins the doctoral program at the same point. For example, some may not have had prior K-12 teaching experience. Others have mentored student teachers or delivered professional development concomitantly with their classroom teaching; however, we believe that most beginning doctoral students will need opportunities to observe science teacher educators teaching teachers before striking out on their own. In addition to observing, the $\mathrm{PhD}$ student needs to reflect explicitly about how the instructor has developed and implemented PCK for teaching science teachers. Vignette 1 (see V1 on Fig. 2) demonstrates how observation can be partnered with other learning experiences at the beginning of the doctoral program to build PCK for teaching teachers.

\section{Apprentice}

To develop PCK for teaching the teachers, the science education PhD student needs to move beyond observing to being an apprentice. The apprentice learns specific knowledge and skills and has a chance to practice in ways that approximate the work of the veteran science teacher educator. Several strategies that are useful in apprenticeship learning experiences were illustrated in Vignette 2 (see V2 on Fig. 2). Park Rogers focused on developing her knowledge of curriculum through reading articles and discussing them with her advisor. Her advisor, an experienced teacher educator, helped her pick out the most important ideas from the readings and think about how they might be applied in teacher education settings. Her advisor modeled the course planning process and Park Rogers had the opportunity to use her knowledge of curriculum for teaching teachers to design a course syllabus. The veteran helped the newcomer approximate best practice through continuous feedback on the syllabus. Thus, the apprentice develops PCK for teaching teachers by actively engaging in discussion with a veteran and by reading about, discussing, and practicing teacher education in small pieces.

\section{Partner}

The next learner role one might experience in becoming a science teacher educator is the methods teaching partnership. During this phase, the veteran teacher educator and the doctoral student work as a team to design and implement a science methods course, or a section of a course. Together they draw upon and put into action aspects of their PCK (knowledge of learner, assessment, curriculum, and instructional strategies) for teaching prospective teachers. As they work together to share and 
reflect upon the experience, they provide each other with feedback about their instruction and about student learning. In Lee's vignette (see V4 in Fig. 2), she moves beyond her earlier apprenticeship to a partnership role where she has the opportunity to teach and assess students in the science methods course with the ongoing support of a faculty member.

\section{Independent Instructor}

The student of teacher education can move from observer to apprentice to partner over several years in the science education doctoral program. At some point, he/she is ready to assume independent responsibility for teaching a methods course. Vignette 4 (see V4 on Fig. 2) demonstrates what happened when an individual became an independent instructor during her doctoral preparation. The independent instructor synthesized the PCK for teaching teachers developed in previous learning experiences, including formal coursework, and applied this knowledge to the task of designing, instructing, and assessing a methods course. The independent instructor also developed new PCK through teaching. The veteran can continue to play a significant role in this stage; however, instead of guiding or co-teaching, the veteran becomes a mentor, periodically observing and providing feedback as needed. The mentor also can be a learner, as described in the final learner role, below.

\section{Mentor}

Developing PCK for teaching teachers is a career-long pursuit. Upon entering the professoriate, individuals assume the role of independent instructors, often without the benefit of mentoring from a veteran. At some point, the new professor will be asked to mentor doctoral students to teach teachers. As the professor helps doctoral students develop PCK for teaching teachers, he/she also continues to reflect upon and enhance his/her own PCK for teaching teachers. Thus, learning from mentoring is an important part of the professional continuum for learning to become a science teacher educator. Vignette 5 (see V5 on Fig. 2) illustrates how a faculty member continued to build PCK for teaching teachers through mentoring doctoral students in a research setting; however, learning from mentoring can also take place in the context of teaching formal courses, supervising apprentices, and co-teaching of methods courses.

\section{Research, Practice, and Policy Implications for Preparing the Next Generation of Science Teacher Educators}

\section{Implications for Science Education Research}

The model we propose is theoretical. Yet it is grounded in our experiences at different universities with the doctoral preparation of future science teacher educators. Furthermore, it is based on the PCK and professional continuum frameworks that have been useful constructs in K-12 science education. With this 
foundation, a research agenda can be set. We need to examine systematically what graduate students learn about teaching science teachers through various experiences as described in our vignettes. We need to study several programs where explicit preparation aimed at the development of PCK for teaching science teachers is a goal. What design decisions were made? What do students experience? How do student learn? How do faculty members learn? How are individual components of PCK applied in an integrated fashion? These kinds of studies will elevate the discussion of how we prepare our doctoral students (What are the essential components of the doctoral programs?) and help refine our proposed model (What sequence is most effective in building PCK?).

\section{Implications for the Design of Science Education Doctoral Programs}

Doctoral programs in science education, like those in many fields, often lack explicit attention to developing future college instructors. If we are to prepare a high quality science teacher educator workforce, we need to turn this situation around. In particular, science educators need to examine the design and delivery of their doctoral programs. Our experiences as doctoral students and faculty members in science education help us to understand that doctoral programs should include an intentional sequence of learning experiences (such as observation of methods instruction; partner and independent teaching of methods courses; coursework directed at science teacher education topics; mentored supervision of field experiences; collaboration in science teacher education research) that lead doctoral students on their trajectories of developing PCK for teaching teachers. We acknowledge that the model we propose here is one possible model for science teacher educator preparation, and will not account for every variation that exists. For example, the situation at some universities may require doctoral students to begin teaching a methods course at the start of their program. Other universities may not have an explicit sequence of experiences, but may rely on doctoral advisors to provide science teacher education experiences to their advisees. In any case, the model can predict experiences that might be less effective in developing PCK for teaching future teachers, such as an independent teaching experience early in the doctoral program (point A on Fig. 2), or a highly structure apprenticeship with little opportunity for instructional decision-making late in the doctoral program (point B on Fig. 2). Thus, we offer this model to provoke discussion about the goals, purposes, and experiences that should be considered in the design of a doctoral program.

Recently at one of our universities, we created an explicit policy for guiding our doctoral program in the area of science teacher education in the form of a set of guidelines for internships in science teacher education. These guidelines acknowledge that learning to teach science teachers is a process that moves individuals from observer to apprentice to partner to independent instructor during the course of their doctoral programs. The guidelines provide structure to the process, by suggesting roles and responsibilities for the doctoral student and for the faculty mentor. We believe that these guidelines will enhance the learning experience for all individuals in our program who desire to become science teacher educators, and could be 
adapted for use in other science education doctoral programs to fit their local needs and context.

\section{Implications for ASTE Policy}

Learning to teach teachers in science teacher preparation programs should be an explicit goal of doctoral programs in science education. ASTE, as the only organization in the world strictly dedicated to the promotion of science teacher education research and practice, has a responsibility to develop policy that can guide programs that prepare science teacher educators. We recommend that ASTE reconsider its Professional Knowledge Standards for Science Teacher Educators (Lederman et al. 1997). Specially, we offer a new standard, Standard 7, which focuses on the development of knowledge about teaching future teachers (see box). This standard could be delineated further through the work of an ASTE committee or task force.

Standard 7: Knowledge for
Teaching Preservice Teachers. The
beginning science teacher educator
possesses knowledge for teaching
teachers of science in preservice
settings, including orientations,
knowledge of preservice teacher
learning, knowledge of methods
course curriculum, knowledge of
instructional strategies for teacher
education, and knowledge of
assessment for methods courses.

\section{Summary}

Although our context was the development of elementary science teacher educators, we believe that our model of the professional continuum for learning to be a science teacher educator is robust enough to include the development of future middle and secondary science teacher educators. Furthermore, some science education doctoral programs include a college science teaching track that prepares individuals for various science education roles at the tertiary level. We believe that the professional continuum model could be extended to apply to individuals in such tracks who plan to work with science faculty and future faculty in professional development our science outreach settings. We believe that designing the infrastructure of learning sequences and strategies that make the development of PCK a regular and deliberate 
part of doctoral programs is essential to preparing the next generation of science teacher educators.

Acknowledgement An earlier version of this paper was presented at the Association for Science Teacher Education annual meeting in January, 2007, in Clearwater Beach, Florida. We wish to thank the following individuals who offered helpful written feedback on our work: Cheryl Bell, Emily Borda, Betsy Davis, Cody Sandifer, and Joe Taylor.

\section{References}

Abell, S. K. (1997). The professional development of science teacher educators: Is there a missing piece? Electronic Journal of Science Education [On-line], 1(4). Retrieved February 2, 2008 from http:// unr.edu/homepage/jcannon/ejse/abell.html.

Abell, S. K. (2003). Reflecting on elementary science. Retrieved October 5, 2008 from http://roes. missouri.edu.

Abell, S. K. (2007). Research on science teacher knowledge. In S. K. Abell \& N. G. Lederman (Eds.), Handbook of research on science education (pp. 1105-1149). Mahwah, NJ: Lawrence Erlbaum.

Abell, S. K., \& Bryan, L. S. (1997). Reconceptualizing the elementary science methods course using a reflection orientation. Journal of Science Teacher Education, 8, 153-166.

Abell, S. K., Bryan, L. A., \& Anderson, M. A. (1998). Investigating preservice elementary science teacher reflective thinking using integrated media case-based instruction in elementary science teacher preparation. Science Education, 82, 491-510.

Abell, S. K., \& Cennamo, K. S. (2004). Videocases in elementary science teacher preparation. In J. Brophy (Ed.), Using video in teacher education (Advances in Research on Teaching, Vol. 10) (pp. 103-129). New York: Elsevier Science.

Akerson, V. L., Abd-El-Khalick, F., \& Lederman, N. G. (2000). Influence of a reflective explicit activitybased approach on elementary teachers' conceptions of nature of science. Journal of Research in Science Teaching, 37, 295-317.

Brown, J. S., Collins, A., \& Duguid, P. (1989). Situated cognition and the culture of learning. Educational Researcher, 18(1), 32-42.

Brown, M. L., Davis, G., Fagen, A. P., Niebur, S. M., \& Wells, K. S. (2001). The 2000 National Doctoral Program Survey. Retrieved February 2, 2008 from http://survey.nagps.org.

Chambers, D. W. (1983). Stereotypic images of scientists: The Draw-A-Scientist test. Science Education, 67, 255-265.

Cochran-Smith, M., \& Zeichner, K. M. (2005). Studying teacher education: The report of the AERA panel on research and teacher education. Mahwah, NJ: Lawrence Erlbaum Associates.

Duckworth, E. (1987). The having of wonderful ideas and other essays on teaching and learning (2nd ed.). New York: Teachers College Press.

Elstgeest, J. (2001). The right question at the right time. In W. Harlen (Ed.), Primary science...taking the plunge: How to teach science more effectively for ages 5 to 12 (2nd ed., pp. 25-35). Portsmouth, NH: Heinemann.

Fagen, A. P., \& Niebur, S. M. (2000, December). Preliminary results for the national doctoral program survey: 32,000 student experiences. Paper presented at the Council of Graduate Schools 40th Annual Meeting, New Orleans, LA.

Feiman-Nemser, S. (2001). From preparation to practice: Designing a continuum to strengthen and sustain teaching. Teachers College Record, 103(6), 1013-1055.

Friedrichsen, P., \& Dana, T. (2003). Using a card sorting task to elicit and clarify science teaching orientations. Journal of Science Teacher Education, 14, 291-301.

Gess-Newsome, J. (1999). Pedagogical content knowledge: An introduction and orientation. In J. GessNewsome \& N. G. Lederman (Eds.), Examining pedagogical knowledge: The construct and its implication for science education (pp. 3-17). Dordrecht: Kluwer Academic Publishers.

Grossman, P. L. (1990). The making of a teacher: Teacher knowledge and teacher education. New York: Teachers College Press.

Harlen, W. (2001). Primary science...taking the plunge: How to teach science more effectively for ages 5 to 12 (2nd ed.). Portsmouth, NH: Heinemann. 
Harlen, W., Macro, C., Reed, K., \& Schilling, M. (2003). Making progress in primary science: A study book for teachers and student teachers. New York: RoutledgeFalmer.

Jablon, P. C. (2002). The status of science education doctoral programs in the United States: The need for core knowledge and skills. Electronic Journal of Science Education, 7(1). Retrieved October 5, 2007 from http://unr.edu/homepage/jcannon/ejse/ejse.html.

Jelly, S. (2001). Helping children raise questions, and answering them. In W. Harlen (Ed.), Primary science...taking the plunge: How to teach science more effectively for ages 5 to 12 (2nd ed., pp. 3647). Portsmouth, NH: Heinemann.

Koch, J. (1990). The science autobiography. Science and Children, 28(3), 42-43.

Lave, J. (1988). Cognition in practice: Mind, mathematics and culture in everyday life. Cambridge: Cambridge University Press.

Lave, J., \& Wenger, E. (1991). Situated learning: Legitimate peripheral participation. Cambridge: Cambridge University Press.

Lederman, N. G., Kuerbis, P., Loving, C., Ramey-Gassert, L., Roychoudhury, A., \& Spector, B. S. (1997). Professional knowledge standards for science teacher educators. Journal of Science Teacher Education, 8, 233-240.

Lortie, D. C. (1975). Schoolteacher: A sociological study. Chicago: University of Chicago Press.

Magnusson, S., Krajcik, J., \& Borko, H. (1999). Nature, sources and development of pedagogical content knowledge for science teaching. In J. Gess-Newsome \& N. G. Lederman (Eds.), Examining pedagogical content knowledge: The construct and its implications for science education (pp. 95132). Boston: Kluwer.

Nyquist, J. D., \& Woodford, B. J. (2000). Re-envisioning the Ph.D. What concerns do we have? Seattle: University of Washington Center for Instructional Development and Research.

Rogoff, B. (1990). Apprenticeship in thinking: Cognitive development in social context. Oxford: Oxford University Press.

Russell, T., \& Martin, A. K. (2007). Learning to teach science. In S. Abell \& N. Lederman (Eds.), Handbook of research on science education (pp. 1151-1178). Mahwah, NJ: Lawrence Erlbaum Associates.

Shulman, L. S. (1986). Those who understand: Knowledge growth in teaching. Educational Researcher, 15(2), 4-14. 